\title{
Microbiological analysis of drinking water from water vending machines
}

\author{
Mustapha Salisu Muhammad a, Mohd Firdaus Abdul-Wahab a, Mohammad Abdul Razis Saidin ${ }^{\mathrm{b}}$, \\ Muhammad Hariz Asraf ${ }^{b}$, Nik Ahmad Nizam Nik Malek a,c,
}

a Department of Biosciences, Faculty of Science, Universiti Teknologi Malaysia, 81310 UTM Skudai, Johor, Malaysia

${ }^{b}$ Advanced Membrane Technology Research Centre (AMTEC), Universiti Teknologi Malaysia, 81310 UTM Skudai, Johor, Malaysia

c Centre for Sustainable Nanomaterials (CSNano), Ibnu Sina Institute for Scientific and Industrial Research (ISI-SIR), Universiti Teknologi Malaysia, 81310 UTM Skudai, Johor, Malaysia

* Corresponding author: niknizam@fbb.utm.my

\section{Article history}

Received 5 January 2019

Revised 14 February 2019

Accepted 11 March 2019

Published Online 15 April 2020

\section{Graphical abstract}
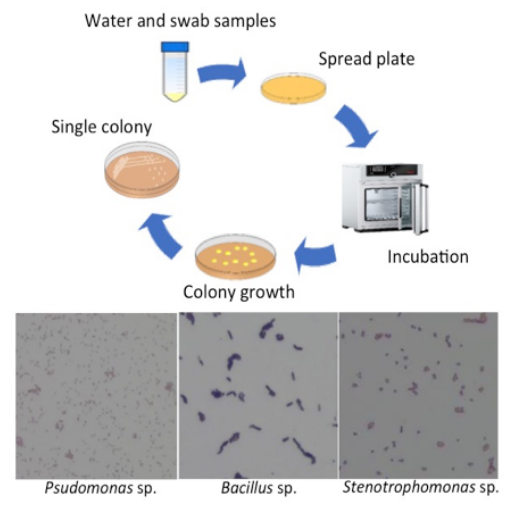

\begin{abstract}
Commercial water vending machines are gaining popularity nowadays among the general public, probably due to the ease of obtaining clean drinking water. However, improper maintenance of the machines can lead to bacterial contamination. Hence, this study aimed to investigate and determine the microbiological characteristics of drinking water from Water Vending Machines (WVM) by isolating and characterizing culturable bacteria in the water and nozzle swab samples. The samples were obtained from WVM at eight different locations around Johor Bahru, Johor, Malaysia. Several unique bacterial isolates were found, from both Gram-positive and Gram-negative groups. Polymerase chain reaction amplification and 16S rRNA sequence analysis suggested that these isolates are from Pseudomonas, Bacillus, and Stenotrophomonas genera. In situ water quality tests which include $\mathrm{pH}$, conductivity, and total dissolved solids were also conducted. Two samples from the inlet source have $\mathrm{pH}$ and conductivity values slightly above the reference values stipulated in drinking water regulations. The findings presented here suggest the importance of regular service maintenance of the WVM to ensure that the water samples meet the standard stipulated by the authority.
\end{abstract}

Keywords: Bacterial isolation, drinking water, water vending machines, public health

\section{INTRODUCTION}

Transmission of waterborne diseases is still a vital issue nowadays, despite multiple efforts worldwide to produce safer drinking water [1]. Low water quality can be due to contamination at the source, human error, and technical failures [2]. Microbial contamination is among the most critical issue as it can directly affect the human health [3]. Drinking water has been reported to contain heterotrophic bacteria, including opportunistic pathogens that are able to cause both nosocomial and community-acquired infections [4]. Up to 663 million people still lack access to good drinking water, and 1.8 billion people still use drinking water that is potentially contaminated $[5,6]$.

Water vending machines (WVM) are rapidly gaining popularities, especially in Malaysia. These machines typically require service maintenance, that include annual replacement of ultraviolet lamp, frequent change of carbon filters, and replacement of the reverseosmosis membrane after a year of operation [4]. Nevertheless, water quality from WVM may quickly deteriorate due to day to day activities in the surrounding area [7]. In addition, the machines can be contaminated with heterotrophic bacteria, especially its inner surface or nozzle dispenser [8].

Previously, six out of 14 samples randomly picked from several places in Kuala Lumpur, Malaysia were found to have either coliform or Escherichia coli and did not contain free chlorine for disinfection purposes [9]. Similar cases were also reported in Los Angeles [10] and Dubai [11]. All cases were concluded to be related to the poor maintenance and improper hygienic conditions of the machines. Thus, this study reports on the performance and characteristics of WVM in different locations around Johor Bahru, Malaysia in terms of physical, chemical, and microbiological parameters.

\section{EXPERIMENTAL}

\section{Sampling}

Water samples were collected from eight different locations in the vicinity of Universiti Teknologi Malaysia (UTM), four within UTM and the remaining four were collected from residential areas namely Taman Sri Pulai Perdana (TSP), Taman Universiti (TU), Taman Mutiara Rini (TR), and Taman Tun Aminah (TA) (Table 1).

From each WVM, samples were collected from dispense nozzle of the machines represented as $(\mathrm{N})$, using a sterile cotton swab by gently and firmly swabbing inside the surface. The swab was then kept in a sterile $15 \mathrm{~mL}$ Falcon tube containing $3 \mathrm{~mL}$ Nutrient Broth (NB) for bacterial cultivation. The other samples taken were outlet sample (O), collected in a $100 \mathrm{~mL}$ sterile Falcon tube and kept cold. For the in situ measurements, samples were collected in $1 \mathrm{~L}$ plastic container from the inlet water (main source) and the outlet (drains). The samples were 
immediately transported to the laboratory for bacterial cultivation, and stored at $4^{\circ} \mathrm{C}$ prior to use.

Table 1 Water sample characteristics based on in situ analysis from eight WVM.

\begin{tabular}{clccc}
\hline $\begin{array}{c}\text { Sample } \\
\text { (Location) }\end{array}$ & Type & pH & $\begin{array}{c}\text { Conductivity } \\
(\boldsymbol{\mu S} / \mathbf{c m})\end{array}$ & $\begin{array}{c}\text { TDS } \\
(\mathbf{m g} / \mathbf{L})\end{array}$ \\
\hline \multirow{2}{*}{ S1 (UTM) } & Inlet & $8.0 \pm 0.1$ & $236.3 \pm 2.6$ & $51.0 \pm 1.1$ \\
& Outlet & $8.0 \pm 0.1$ & $251.0 \pm 3.0$ & $52.7 \pm 0.7$ \\
\hline \multirow{2}{*}{ S2 (UTM) } & Inlet & $8.0 \pm 0.0$ & $244.0 \pm 1.1$ & $52.0 \pm 0.7$ \\
& Outlet & $8.0 \pm 0.1$ & $249.0 \pm 0.7$ & $53.0 \pm 0.0$ \\
\hline \multirow{2}{*}{ S3 (UTM) } & Inlet & $8.0 \pm 0.0$ & $252.0 \pm 1.1$ & $53.0 \pm 0.7$ \\
& Outlet & $7.0 \pm 0.0$ & $252.0 \pm 0.7$ & $53.0 \pm 0.0$ \\
\hline \multirow{2}{*}{ S4 (UTM) } & Inlet & $8.0 \pm 0.0$ & $274.0 \pm 5.6$ & $53.0 \pm 0.7$ \\
& Outlet & $7.0 \pm 0.0$ & $257.0 \pm 4.1$ & $52.0 \pm 0.7$ \\
\hline \multirow{2}{*}{ S5 (TSP) } & Inlet & $9.0 \pm 0.0$ & $264.0 \pm 3.3$ & $53.0 \pm 0.0$ \\
& Outlet & $8.0 \pm 0.0$ & $280.7 \pm 2.4$ & $55.0 \pm 0.2$ \\
\hline \multirow{2}{*}{ S6 (TU) } & Inlet & $8.0 \pm 0.0$ & $272.0 \pm 2.4$ & $53.0 \pm 0.7$ \\
& Outlet & $8.0 \pm 0.1$ & $210.0 \pm 1.7$ & $39.0 \pm 0.7$ \\
\hline \multirow{2}{*}{ S7 (TR) } & Inlet & $8.0 \pm 0.0$ & $275.0 \pm 4.3$ & $52.0 \pm 0.7$ \\
& Outlet & $7.0 \pm 0.1$ & $220.0 \pm 6.9$ & $50.0 \pm 1.3$ \\
\hline \multirow{2}{*}{ S8 (TA) } & Inlet & $7.0 \pm 0.0$ & $1252.0 \pm 7.9$ & $241.0 \pm 2.0$ \\
& Outlet & $7.0 \pm 0.1$ & $207.0 \pm 3.0$ & $48.0 \pm 2.4$ \\
\hline \multirow{2}{*}{ TTDS: Tot } & & &
\end{tabular}

*TDS: Total Dissolved Solids

\section{In Situ analysis}

$\mathrm{pH}$ was analyzed using HM Digital pH-200, conductivity was analyzed using KEDIDA Pocket Conductivity Meter CT-3031, and total dissolved solids (TDS) were measured using SenION 5 (HACH). The measurements were done in triplicates.

\section{Bacterial cultivation}

Both the collected samples from the swab dispense nozzle and the outlet source were used as culture source. About $0.1 \mathrm{~mL}$ of each sample was spread onto Nutrient Agar (NA) and incubated at $37{ }^{\circ} \mathrm{C}$ overnight. Distinct single colonies were sub-cultured on a fresh NA plate by serial streaking and incubated overnight at $37{ }^{\circ} \mathrm{C}$. The bacterial isolates were sub-cultured again until a single pure isolate was obtained.

\section{Bacterial identification}

The pure isolates were identified through morphological observation, Gram staining, and 16S rRNA gene analysis. Each single colony was inoculated in NB and incubated at $30{ }^{\circ} \mathrm{C}$ overnight with shaking at $200 \mathrm{rpm}$ until the optical density at $600 \mathrm{~nm}$ reached $0.7-1.0$. Genomic DNA extraction was performed using the Wizard ${ }^{\circledR}$ Genomic DNA Purification Kit (Promega) according to the manufacturer's instruction.

The 16S rRNA gene of the bacterial isolate was amplified using a set of universal primers: forward primer (27F) (5'-AGAGTT TGATCCTGGCTCAG-3') and reverse primer (1492R) (5' CGGTTACCTTGTTACGACTT 3'). PCR amplification was conducted with a mixture component containing $25 \mu \mathrm{L}$ total reaction volume. All the other reaction components include $12.5 \mu \mathrm{L}$ GoTaq Green Master Mix, $0.75 \mu \mathrm{L}$ forward primer, $0.75 \mu \mathrm{L}$ reverse primer, 2 $\mu \mathrm{L}$ DNA template, and $25 \mu \mathrm{L}$ nuclease-free water . Amplification was done in a thermocycler (GeneAmp PCR System 9700) using the following cycle: initial denaturation at $95{ }^{\circ} \mathrm{C}$ for $4 \mathrm{~min}$; 30 cycles of denaturation for $1 \mathrm{~min}$ at $95{ }^{\circ} \mathrm{C}$, annealing for 30 secs at $55{ }^{\circ} \mathrm{C}$, extension for $2 \mathrm{~min}$ at $72{ }^{\circ} \mathrm{C}$; and a final extension at $72^{\circ} \mathrm{C}$ for $5 \mathrm{~min}$.
The PCR product was visualized using gel electrophoresis under UV illumination using Gene Flash Gel Documentation System. The amplified 16S rRNA gene was sent to First Base Laboratories (Malaysia) Sdn. Bhd. for sequencing. The resulting sequences were then subjected to Basic Local Alignment Search Tool (BLAST) analysis. Phylogenetic and molecular evolutionary analyses were conducted using MEGA version 6 [12] and ClustalW.

\section{RESULTS AND DISCUSSION}

The values of the selected water parameters $(\mathrm{pH}$, conductivity, and TDS) for all the samples are shown in Table 1. Several standards were used for comparison, namely the National Water Quality Standards for Malaysia (NWQSM), Malaysian Drinking Water Standard (MDWS), World Health Organisation (WHO), and United States Environmental Protection Agency (US EPA).

The $\mathrm{pH}$ of drinking water as recommended by WHO and US EPA lies between 6.5-8.5 [7], which corresponds to that of NWQSM and MDWS. In this study, $\mathrm{pH}$ of the water samples is in the range of 7-9. Only one of the samples from inlet source of the WVM exceeds the acceptable limit, namely the S5 inlet water, which may affect its quality [13]. Conductivity varied with values between 200-1260 $\mu \mathrm{S} / \mathrm{cm}$ (except for S8 inlet), which are consistent with NQSM, WHO, and US EPA which limit between 10 and $1000 \mu \mathrm{S} / \mathrm{cm}$. Water conductivity is usually affected by inorganic dissolved solids such as aluminium, cations, calcium, chloride, iron, magnesium, nitrate, sodium, and sulphates [14]. It can also be influenced by organic compounds such as phenols, oil, alcohol, and sugar. Additionally, temperature can also affect water conductivity. The TDS values ranged from around $40-250 \mathrm{mg} / \mathrm{L}$, for all samples. Standards by NQSM, MDWQ, WHO and US EPA state that the TDS value should not exceed $1000 \mathrm{mg} / \mathrm{L}$. TDS is usually comprised of inorganic salts and small amount of organic matter dissolved in the water.

Generally, all water samples from the WVM comply with the standards set, except for one inlet sample. The deviation is probably due to the affected water supply quality in the specific area. Treatments provided by the WVM has also successfully achieved the required physicochemical parameters as outlined in drinking water standards. These parameters are critical, as they may affect bacterial growth on the surface of the machines [15].

A total of 20 isolates from both Gram-negative and Gram-positive groups with different morphological features have been successfully cultivated from the WVM samples. PCR amplification of the $16 \mathrm{~S}$ rRNA gene and sequencing analysis has successfully been carried out to determine the identity of the isolates, which closely related to three different genera: Bacillus, Pseudomonas, and Stenotrophomonas (Table 2). Half of the isolates are closely-related to Stenotrophomonas sp., $40 \%$ are Bacillus sp., and $10 \%$ are Pseudomonas sp. While it is difficult to know the effects of the presence of these bacteria in the water samples, it is possible that this is caused by inadequate disinfection [8] or poor maintenance [10].

Stenotrophomonas is a Gram-negative bacillus, typically found in soil and water and not part of normal human flora. The genus is found to occur ubiquitously in the environment, exists by living freely or plant-associated. It is also an opportunistic pathogen [16]. Stenotrophomonas sp. has been isolated from sponges (Gelliodes sp.) at Pahang coastal water [17]. S. maltophilia can be found in different environmental niches including soils, plant rhizosphere, surface water, wastewater, drinking water and food, and in contaminated medical care fluids [18-20]. It has the ability to form biofilm by adhering to various biotic and abiotic surfaces that may contribute to contamination in municipal water supplies, taps, and drains, water purification systems, air conditioning and other cooling systems, and medical devices [19]. S. maltophilia has also been found in water fountains [21]. It is recognized as an emerging opportunistic pathogen causing nosocomial infections in immune-compromised patients [20, $22,23]$. WHO has declared S. maltophilia as one of the top drugresistant pathogens in hospitals worldwide [24]. In our study, S6-1O, S8-1O, and S4N are closely-related to S. maltophilia with $96 \%, 82 \%$, 
and $86 \%$ identity, respectively. This warrants a further investigation to confirm the exact species of the isolates.

Table 2 Identity of the isolated bacteria from the WVM samples.

\begin{tabular}{|c|c|c|c|c|}
\hline Sample & Source & Isolate & $\begin{array}{l}\text { Closest Similarity (up } \\
\text { to genus level) }\end{array}$ & $\begin{array}{c}\text { Identity } \\
(\%)\end{array}$ \\
\hline \multirow{3}{*}{$\mathrm{S} 1$} & Nozzle & $\mathrm{S} 1 \mathrm{~N}$ & Pseudomonas sp. & 91 \\
\hline & \multirow{2}{*}{ Outlet } & S1-10 & Bacillus sp. & 91 \\
\hline & & $\mathrm{S} 1-2 \mathrm{O}$ & Stenotrophomonas sp. & 86 \\
\hline \multirow{3}{*}{$\mathrm{S} 2$} & Nozzle & $\mathrm{S} 2 \mathrm{~N}$ & Bacillus sp. & 97 \\
\hline & \multirow{2}{*}{ Outlet } & S2-10 & Stenotrophomonas sp. & 95 \\
\hline & & $\mathrm{S} 2-2 \mathrm{O}$ & Bacillus sp. & 98 \\
\hline \multirow{2}{*}{ S3 } & Nozzle & S3N & Bacillus sp. & 93 \\
\hline & Outlet & $\mathrm{S} 3 \mathrm{O}$ & Bacillus sp. & 91 \\
\hline \multirow{2}{*}{ S4 } & Nozzle & S4N & Stenotrophomonas sp. & 89 \\
\hline & Outlet & $\mathrm{S} 4 \mathrm{O}$ & Bacillus sp. & 89 \\
\hline \multirow{2}{*}{ S5 } & Nozzle & S5N & Stenotrophomonas sp. & 86 \\
\hline & Outlet & $\mathrm{S} 5 \mathrm{O}$ & Stenotrophomonas sp. & 96 \\
\hline \multirow{3}{*}{ S6 } & Nozzle & $\mathrm{S} 6 \mathrm{~N}$ & Bacillus sp. & 91 \\
\hline & \multirow{2}{*}{ Outlet } & S6-10 & Stenotrophomonas sp. & 96 \\
\hline & & S6-2O & Stenotrophomonas sp. & 87 \\
\hline \multirow{2}{*}{ S7 } & Nozzle & S7N & Stenotrophomonas sp. & 91 \\
\hline & Outlet & $\mathrm{S} 7 \mathrm{O}$ & Pseudomonas sp. & 91 \\
\hline \multirow{3}{*}{ S8 } & Nozzle & S8N & Stenotrophomonas sp. & 87 \\
\hline & \multirow{2}{*}{ Outlet } & $\mathrm{S} 8-10$ & Stenotrophomonas sp. & 82 \\
\hline & & S8-2O & Bacillus sp. & 91 \\
\hline
\end{tabular}

Bacillus sp. is ubiquitous in the environment, especially in soil water and air, with optimum growth at $20-40{ }^{\circ} \mathrm{C}$. However, B. cereus is also able to produce toxins responsible for foodborne illnesses, causing vomiting or diarrhoea. It can be found in fresh and marine waters, vegetables, fomites, intestinal tract of invertebrates, and decaying organic matter [25]. Due to the wide distribution of the spore in the environment, especially in soils, they can be easily spread out into water, dust, and food [26-28], potentially leading to contamination of water supply and also WVM. B. cereus has the ability to produce biofilm [29], and has been found in vending machines [30,31]. In our study, isolates $\mathrm{S} 2 \mathrm{~N}, \mathrm{~S} 3 \mathrm{O}, \mathrm{S} 4 \mathrm{O}, \mathrm{S} 2-2 \mathrm{O}, \mathrm{S} 3 \mathrm{~N}$, and $\mathrm{S} 1-1 \mathrm{O}$ are found to be closely-related to B. cereus.

Pseudomonas is another abundant bacteria in the environment [32]. Most of the Pseudomonas. sp discovered from water are found to be resistant to antimicrobial agents [1]. P. aeruginosa has been reported in water dispensers and vending machines [4,11]. Similarly, a study on drinking water samples (bottled water, water cooler units, and tap water) was found to have $2-3 \%$ of $P$. aeruginosa [33]. $P$. aeruginosa has the ability to adhere to the surface of WVM such as buttons andnozzles to form biofilms [34].

On the basis of the results obtained, of the 18 samples examined, bacterial colonies were found to be present in all nozzle and outlet samples. Some of these bacteria have the potential to be nosocomial or opportunistic pathogens. Previous studies have reported that Proteobacteria, Actinobacteria, Firmicutes, and Bacteriodetes are commonly found in drinking water networks [32, 35], in polluted environments, and clinical samples [36]. Regardless of the location, we can conclude that regular cleaning and maintenance of the WVM is imperative to maintain the quality of the water supplied. Antibacterial materials can also be incorporated into the WVM components to avoid the formation of bacterial biofilm on the surfaces.

\section{CONCLUSION}

The TDS of all the WVM samples were found within the threshold range, while the $\mathrm{pH}$ and conductivity were slightly above the permissible limit stipulated by the various regulatory bodies. Microbiology analysis revealed that the majority of the cultivable bacteria present in the samples are from the phylum Proteobacteria and Firmicutes. Some bacterial species are potentially the ones associated with contaminated water, although a full identification is necessary to confirm the species. Nevertheless, we can conclude that regular cleaning and maintenance of the WVM is critical. The placement of the machines should also be considered so that it is not easily exposed to sources of contamination.

\section{ACKNOWLEDGEMENT}

The authors would like to acknowledge the Advanced Membrane Technology Research Centre (AMTEC) and Universiti Teknologi Malaysia for the fund provided through HICoE research grant 4J198.

\section{REFERENCES}

[1] Da Silva, M. E. Z., Santana, R. G., Guilhermetti, M., Camargo Filho, I., Endo, E. H., Ueda-Nakamura, T., Nakamura, C. V. and Dias Filho, B. P. (2008). Comparison of the bacteriological quality of tap water and bottled mineral water. International Journal of Hygiene and Environmental Health. 211(5), 504-509.

[2] Roefer, P. A., Monscvitz, J. and Rexing, D. J. (1996). The Las Vegas cryptosporidiosis outbreak. Journal-American Water Works Association. 88(9), 95-106.

[3] Farkas, A., Drăgan-Bularda, M., Ciatarâş, D., Bocoş, B. and Ţigan, Ş. (2012). Opportunistic pathogens and faecal indicators in drinking water associated biofilms in Cluj, Romania. Journal of Water and Health. 10(3), 471-483.

[4] Chaidez, C., Rusin, P., Naranjo, J. and Gerba, C. P. (1999). Microbiological quality of water vending machines. International Journal of Environmental Health Research. 9(3), 197-206.

[5] WHO (2015). Progress on sanitation and drinking water: 2015 update and MDG assessment. World Health Organization.

[6] WHO (2006). Guidelines for drinking-water quality [electronic resource]: incorporating first addendum. Vol. 1, Recommendations. 3rd ed Switzerland WHO Press, World Health Organization.

[7] Ali, S. S., Anwar, Z. and Khattak, J. Z. K. (2012). Microbial analysis of drinking water and water distribution system in new urban Peshawar. Current Research Journal of Biological Sciences. 4(6), 731-737.

[8] Ee, Y. T., Arifullah, M. and Jan, M. S. (2016). Identification of escherichia coli strains from water vending machines of Kelantan, Malaysia using 16S rRNA gene sequence analysis. Exposure and Health. 1-6.

[9] Hashim, N. and Yusop, H. (2016). Drinking Water Quality of Water Vending Machines in Parit Raja, Batu Pahat, Johor. Proceedings of the 2016 IOP Conference Series: Materials Science and Engineering. 136(1), 012053.

[10] Schillinger, J. and Knorr, S. D. V. (2004). Drinking-water quality and issues associated with water vending machines in the city of Los Angeles. Journal of Environmental Health. 66(6), 25.

[11] Al Moosa, M. E., Khan, M. A., Alalami, U. and Hussain, A. (2015). Microbiological quality of drinking water from water dispenser machines. International Journal of Environmental Science and Development. 6(9), 710-713.

[12] Tamura, K., Stecher, G., Peterson, D., Filipski, A. and Kumar, S., (2013). MEGA6: molecular evolutionary genetics analysis version 6.0. Molecular Biology and Evolution, 30(12), 2725-2729.

[13] Mako, S., Harrison, M., Sharma, V. and Kong, F. (2014). Microbiological quality of ice made and bagged on-premises in retail stores and in self-service vending machines in comparison to manufactured produced ice in Georgia. University of Georgia. 15-55.

[14] Al-Badaii, F., Shuhaimi-Othman, M. and Gasim, M. B. (2013). Water quality assessment of the Semenyih river, Selangor, Malaysia. Journal of Chemistry. 2013, ID 871056.

[15] Pratum, C. and Khananthai, N. (2017). Assessment of factors affecting drinking water quality from free water dispensers in the higher education institution. International Journal of Environmental and Science Education. 12(4), 787-797.

[16] Ramos, P. L., Van Trappen, S., Thompson, F. L., Rocha, R. C., Barbosa, H. R., De Vos, P. and Moreira-Filho, C. A. (2011). Screening for endophytic nitrogen-fixing bacteria in Brazilian sugar cane varieties used in organic farming and description of Stenotrophomonas pavanii $\mathrm{sp}$. nov. International journal of Systematic and Evolutionary Microbiology. 61(4), 926-931.

[17] Hamid, T. H. T. A., Abdul, A. A. and Hamid, N. H. P. (2015). Isolation of moderately halophilic lipase producing bacteria from sponges in pahang coastal water, malaysia. Jurnal Teknologi. 77(25), 57-61.

[18] Looney, W. J., Narita, M. and Mühlemann, K. (2009). Stenotrophomonas maltophilia: an emerging opportunist human pathogen. The Lancet Infectious Diseases. 9(5), 312-323. 
[19] Mahdi, O., Eklund, B. and Fisher, N. (2014). Stenotrophomonas maltophilia: Laboratory Culture and Maintenance. Current Protocols in Microbiology. 32, 1-9.

[20] Ryan, R. P., Monchy, S., Cardinale, M., Taghavi, S., Crossman, L., Avison, M. B., Berg, G., Van Der Lelie, D. and Dow, J. M. (2009). The versatility and adaptation of bacteria from the genus Stenotrophomonas. Nature Reviews Microbiology. 7(7), 514-525.

[21] Mustafa, N., Ibrahim, B., Jasim, M., Salim, M., Abdalla, Q. and Saleh, S. (2015). Diversity and antibiotic susceptibilities of bacterial species from surfaces of publicly used equipment in a medical education setting. African Journal of Microbiology Research. 9(45), 2239-2248.

[22] Adamek, M., Overhage, J., Bathe, S., Winter, J., Fischer, R. and Schwartz, T. (2011). Genotyping of environmental and clinical Stenotrophomonas maltophilia isolates and their pathogenic potential. PLoS One. 6(11), e27615.

[23] Elting, L. S., Khardori, N., Bodey, G. P. and Fainstein, V. (1990). Nosocomial infection caused by Xanthomonas maltophilia: a casecontrol study of predisposing factors. Infection Control and Hospital Epidemiology. 11(3) 134-138.

[24] Brooke, J. S. (2014). New strategies against Stenotrophomonas maltophilia: a serious worldwide intrinsically drug-resistant opportunistic pathogen. Journal Expert Review of Anti-infective Therapy. 12(1), 1-4.

[25] Jensen, G., Hansen, B., Eilenberg, J., and Mahillon, J. (2003). The hidden lifestyles of Bacillus cereus and relatives. Environmental Microbiology, 5, 631-640.

[26] Bottone, E. J. (2010). Bacillus cereus, a volatile human pathogen. Clinical Microbiology Reviews. 23(2), 382-398.

[27] Jenson, I., Moir, C. and Hocking, A. (2003). Bacillus cereus and other Bacillus species. Foodborne Microorganisms of Public Health Significance. 445-478.
[28] Logan, N. A. and Vos, P. D. (2015). Bacillus. Bergey's Manual of Systematics of Archaea and Bacteria.

[29] Auger, S., Ramarao, N., Faille, C., Fouet, A., Aymerich, S. and Gohar, M. (2009). Biofilm formation and cell surface properties among pathogenic and nonpathogenic strains of the Bacillus cereus group. Applied and Environmental Microbiology. 75(20), 6616-6618.

[30] Nelms, P. K., Larson, O. and Barnes-Josiah, D. (1997). Time to B. Cereus about hot chocolate. Public Health Reports. 112(3), 240.

[31] Hall, A. (2008). Microbiological risks associated with hot-drinks vending. University of Wales.

[32] Martiny, A. C., Albrechtsen, H.-J., Arvin, E. and Molin, S. (2005). Identification of bacteria in biofilm and bulk water samples from a nonchlorinated model drinking water distribution system: detection of a large nitrite-oxidizing population associated with Nitrospira spp. Applied and Environmental Microbiology. 71(12), 8611-8617.

[33] Edberg, S., Gallo, P. and Kontnick, C. (1996). Analysis of the virulence characteristics of bacteria isolated from bottled, water cooler, and tap water. Microbial Ecology in Health and Disease. 9(2), 67-77.

[34] Bloomfield, S. F. (2012). The chain of infection transmission in the home and everyday life settings, and the role of hygiene in reducing the risk of infection. Simmons College, Boston, MA USA.

[35] Falcone-Dias, M. F., Vaz-Moreira, I. and Manaia, C. M. (2012). Bottled mineral water as a potential source of antibiotic resistant bacteria. Water Research. 46(11), 3612-3622.

[36] Han, J. I., Choi, H. K., Lee, S. W., Orwin, P. M., Kim, J., LaRoe, S. L., Kim, T., O’Neil, J., Leadbetter, J. R., Lee, S. Y., Hur, C. G., Spain, J. C., Ovchinnikova, G., Goodwin, L and Han, C. (2011). Complete genome sequence of the metabolically versatile plant growth-promoting endophyte Variovorax paradoxus S110. Journal of Bacteriology, 193(5), 1183-1190. 